\title{
ECONOMIC AND LOGISTICAL VIABILITY OF PRODUCTION OF FRESHWATER ANGELFISH (PTEROPHYLLUM SCALARE)
}

\author{
TAKATSUKA, V. ${ }^{1 ;}$ NAVARRO, R. D. ${ }^{{ }^{*}}$ \\ 1. Laboratório de Aquicultura e de Biotecnológica de Organismos Aquáticos, Faculdade de Agrono- \\ mia e Medicina Veterinária, Universidade de Brasília, Brasília, DF, Brazil. \\ *Corresponding author: navarrounb@gmail.com
}

\begin{abstract}
TAKATSUKA, V. \& NAVARRO, R. D. (2018). Economic and Logistical Viability of Production of Freshwater Angelfish (Pterophyllum scalare). Braz. J. Aquat. Sci. Technol. 22(1). elSSN 1983-9057. DOI: 10971/bjast.v22n1. The freshwater Angelfish stands out for being one of the most beautiful, best-selling and also most popular ornamental fish of tropical waters. Its cultivation is concentrated in the southeastern and southern regions of Brazil, so reproduction of this species in other areas can become a profitable venture. The present study analyzed the economic viability of the cultivation of the freshwater Angelfish, Pterophyllum scalare, in a water recirculation system. To measure the market demand, an interview was conducted with the main tenants in the industry, adding to the estimate. The profitability of the venture was $2,65 \%$ in the first year and $11,95 \%$ in the second to the tenth year and the payback rate was 38 months or 3 years and 2 months. Small-scale farming proved to be economically viable, presenting attractive profitability indicators compared to other aquaculture enterprises.
\end{abstract}

Key Words: Aquaculture; Pisciculture; Aquarism; Cultivation; Ornamental fish.

\section{INTRODUCTION}

Currently, the ornamental fish population kept as pets in Brazil totalizes 25.5 million individuals. This number, estimated by the Brazilian Association of Pet Products Industry (ABINPET) (MPA, 2014). With varying acquisition and maintenance costs, ornamental fish fit into any family budget. Among the species of ornamental fish, the freshwater Angelfish, Pterophyllum scalare Lichtenstein (1823), stands out as being one of the most beautiful, best-selling and also most popular ornamental fish of tropical waters (Chapman et al., 1997). This species forms couples that defend their territory (Cacho et al., 1999) and, after the cut, deposit their adhesive eggs on a flat surface. In planted aquaria they prefer broad-leafed plants such as Anubia sp or Amazonian Echinodorus amazonensis (Cacho et al., 1999), but may spawn on stones or flat trunks, in the aquarium glass, thermostat or internal filter (Mathias et al., 2010).

According to Mathias et al. (2010) the commercial breeders of this species are concentrated in the southeast and south of Brazil, in the states of São Paulo, Minas Gerais, Rio de Janeiro and Paraná. Due to this, the creation of this species in other areas like Center-West and Northeast would be a great opportunity to assist shopkeepers, who would ['will' is definitive, 'would' is a possibility] have their cost of acquisition of these animals reduced, because of the cheapening or even elimination of freight, which is up to five times the value of a specimen. In addition to the tenants, another possible target audience for the venture is the end consumer. Fans of the species can be affected by the disclosure and online sales.

The water recirculation system is suitable for the cultivation of ornamental fish, because it consumes less water, allowing the installation of the project closer to the consumer market, in addition to providing better control of water quality and reducing the risks of pathogen introduction (Halachmi, 2006). The present work evaluates the economic viability of implantation and maintenance of a breeding ground of freshwater Angelfish.

\section{MATERIAL AND METHODS}

\section{Market research}

Market research enables the identification of potential consumers and competitors, as well as their preferences, habits and customs. It allows estimation of demand forecast and market potential, and may indicate the trend of new business (Almeida, 2016). The questionnaire below was applied to the 10 main aquarist stores in the city of Brasília - Distrito Federal. 


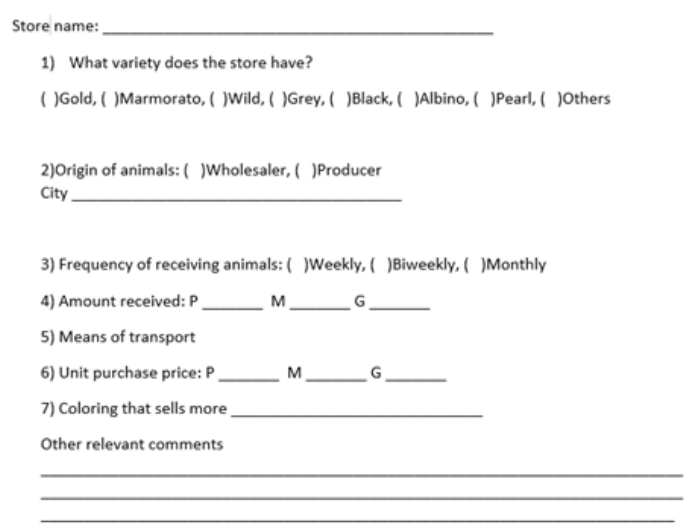

Figure 1- Questionnaire model used for the market research of freshwater Angelfish (Pterophyllum scalare).

\section{Installations}

The project will consist of eight recirculation systems composed (Figure 2) of thermoregulated water circulating between the aquariums and the mechanical and biological filters recommended by Piedrahita (2003). The larviculture sector will not use recirculation system; due to the fragility of the organisms, only aeration and partial water exchange was recommended, as in the research of Kodama et al. (2011). The greenhouse was designed with 17 boxes of $600 \mathrm{~L}$ with 4 filter sets, 32 tanks of $80 \mathrm{~L}$ for the maintenance of couples with 2 filter sets, 36 for larviculture and 34 for growth with 2 filter sets each, arranged according to Figure 2. In the breeding sector, the breeding diet will be the basis of commercial feed and PVC plaques will be used as a substrate for spawning, which after 24 hours of spawning, the adhesive eggs will be transferred to the larviculture sector.

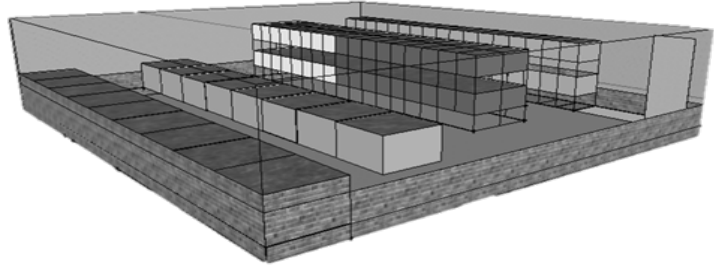

Figure 2- 3D view of the construction model of a greenhouse for freshwater Angelfish Pterophyllum scalare. It is understood that the two rows on the right are $600 \mathrm{~L}$ boxes for the formation of couples and final growth of fish, in the aquarium batteries we have blank places for maintenance of couples formed, dark gray larviculture and light gray aquariums for growth.

\section{Cultivation Technique}

When the couple lives with their offspring and exhibits their parental care, the interval between spawning is more than 25 days, usually 30 to 40 days. If spawning is withdrawn and incubated separately, the female will spawn again after 7 to 12 days if temperature and adequate nutrition are maintained (Vidal Jr,
2007). $48 \mathrm{~h}$ after fertilization, the larvae hatched from the eggs, feeds exclusively from the yolk sac reserve and presents the immature gastrointestinal tract and closed oral opening (Ribeiro et al, 2007). The feeding scheme during development is demonstrated in Table 1.

Table 1- Development and feeding indicated for the o freshwater Angelfish (Pterophyllum scalare) during its initial stage of development.

\begin{tabular}{|c|c|c|c|}
\hline Days & Phase & Feeding & Development \\
\hline-2 & After fertilization & Unnecessary & Egg development \\
\hline 0 & Outbreak & Unnecessary & Larvae hatch \\
\hline $1-3$ & Larva & Unnecessary & Larvae attached to a surface \\
\hline $4-6$ & Post larva & $\begin{array}{l}\text { Phytoplankton, newly } \\
\text { hatched artemia and } \\
\text { vinegar worm }\end{array}$ & $\begin{array}{c}\text { Maturation of the } \\
\text { gastrointestinal tract and swim } \\
\text { bladder }\end{array}$ \\
\hline $8-12$ & Fingerlings & $\begin{array}{l}\text { Newly hatched artemia * } \\
\text { Photoperiod 24h clear }\end{array}$ & $\begin{array}{l}\text { Great growth, fully developed } \\
\text { dorsal and anal fins }\end{array}$ \\
\hline 21 & Fingerlings & $\begin{array}{l}\text { Powdered and crushed } \\
\text { food }\end{array}$ & Appearance similar to an adult \\
\hline
\end{tabular}

Adaptation of Abraham, 2017; Cacho et al., 1999; Ribeiro et al. 2007; Takahashi et al., 2010; Vidal Jr. 2007; *Veras et al.,2016.

The post-larva phase appears around two to four days after hatching. The post-larva has consumed a large part of the yolk sac and has developed swimming bladder, exhibiting horizontal swimming, besides the vertical one present in the larva stage. During this period, diversified live feeding should be started (Vidal Jr, 2007). 8 days after hatching, a photoperiod of $24 \mathrm{~h}$ light and Oh dark, concerning feeding only newly hatched artemia nauplii are offered twice a day at the density of 1000 nauplii per day for each larva (Veras et al., 2016). Feeding with enriched artemia with synbiotic (Pediococcus acidilactici and fructooligosaccharide) is recommended to improve immunity and resistance to stress (Azimirad et al., 2016; Nayak, 2010). The integrated cultivation of freshwater Angelfish was also shown viable with Malaysian prawn (Macrobrachium rosenbergii) (Silva et al., 2008) and Amazon River prawn (Macrobrachium amazonicum) (Ribeiro et al., 2010).

For fingerlings around $150 \mathrm{mg}$ in weight, about 30 days of development, the powdered diet (flocculated and milled by the manufacturer itself, $0.9 \mathrm{~mm}$ ) was the most indicated by Takahashi et al. (2010). This diet is adequate to the size of the oral cavity of the animal and should be offered twice daily in small portions, until the apparent satiation of the animals. This food presented 
a better growth result, without affecting the water quality, with daily partial changes of $30 \%$ of the volume of the aquarium to remove traces of feed and feces. One must undergo a transition process, popularly known as weaning, with co-feed of live and inert food prior to the commencement of the exclusive diet feed.

\section{Economic analysis}

For the analysis of economic viability, a small-scale production system was defined, that is, an enterprise that serves a regional market and uses a small labor force, but produces the necessary quantity to supply the 10 stores that participated in the survey of the Market-place. We have a couple of freshwater Angelfish that spawns 200 to 300 eggs on average, there are reports that more experienced couples can produce 800 to 1000 eggs. For economic viability calculations we will use 200 eggs per spawn, with $60 \%$ survival rate until the sale phase and, of these survivors, $10 \%$ will be discarded by death or deformation, so each spawn will produce 100 juveniles for sale. We consider 10 spawns per month. For the calculations, it was adopted that house couples will produce 100 fish per month, resulting in R\$ 630.00 equivalent to US\$ 184.59 of sales after completing 6 months of development of the fry. It was considered 200 eggs per spawning, being 10 spawns per month, an underestimated number, since 20 couples will be formed and some spawn more than once a month and 200 to 300 eggs, totaling a $\mathrm{R} \$ 6,300.00$ equivalent to US\$ 18459,37 monthly revenue. For sale, three sizes will be offered and only two color variations.

The present analysis will focus on the production system, addressing the costs and facilities necessary for the reproduction, larviculture and fattening of fish, as well as the production of live food, necessary in the first days of life of the larva. The values used in the calculations were based on the costs practiced in the Brasília - DF region, from October to November 2014.

\section{Return on investment / Profitability indicators}

Cash flow was calculated considering expenses related to the investment and the effective operating cost. The investment recovery period, or payback period, was used to obtain the return period of invested capital and profitability, and profitability can be used to compare the efficiency of this investment with other business options (Faro, 1979).

\section{RESULTS AND DISCUSSION}

Market research has revealed that fish are classified according to size and that the price increases along with the size of the fish. Among the varieties of colors sold, Marmorato (predominant black coloration with random white or yellow spots) was present in $100 \%$ of the stores and is the most bought by aquarists (Figure 3). The wild variety (gray body coloration with black vertical bands) is in second place, with a $70 \%$ presence in the visited stores. Regarding the suppliers, $100 \%$ are wholesalers and the animals are originated from the states of São Paulo, Minas Gerais and Rio de Janeiro. The Brazilian market has the capacity to absorb around 900 freshwater Angelfish per month, thus, there is requirement of at least 9 monthly shots. The routine of the breeder has to adapt to the routine of the store, so the frequency of deliveries should be biweekly. There is demand for three sizes: small, medium and large, which present different selling prices.

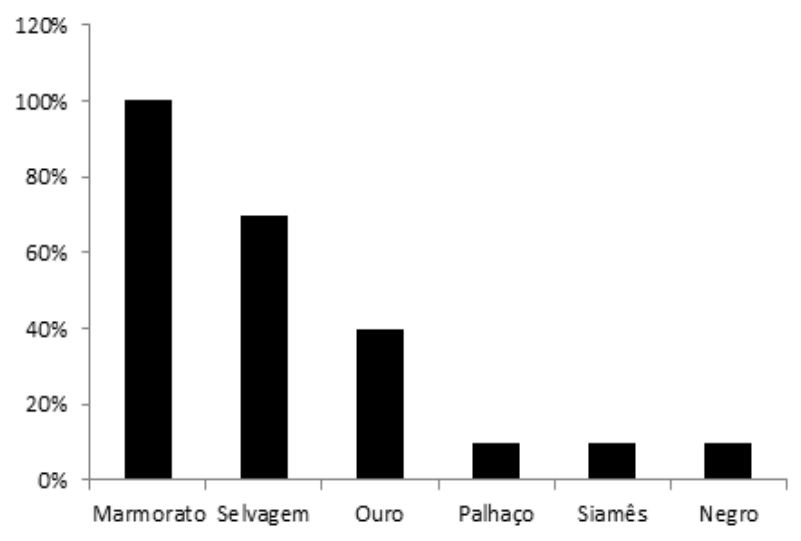

Figure 3- Quantification of the presence of the different varieties freshwater Angelfish in the stores surveyed.

The main form of transportation used is road transport $(90 \%)$. Only one store $(10 \%)$ claimed to receive the species via the carrier, which uses the means of road and air transport, but this establishment had the largest variety and quantity of fish, so the freight can be diluted between species and more expensive varieties.

In a budget requested by the company JadLog, freight carriers are popularly known among sellers of ornamental fish, one kilo of order in the stretch São Paulo - Brasília, costs around R\$27,00 with delivery period of two working days. Being that a small freshwater Angelfish is sold for $\mathrm{R} \$ 3,00$ and the large for $\mathrm{R} \$$ 9,00 by the breeders. One option would be to increase the density of animals per package in order to further dilute the cost of freight, but the species does not support transport with high density of fish, resulting in a high mortality rate. 
Table 2- Estimates of sale for different size classes per couple of freshwater Angelfish (Pterophyllum scalare). Generic classification by size, unit selling price, standard length and months of development according to the results obtained in market research.

\begin{tabular}{ccccc}
\hline Sale by spawn & Classification & Unitary value (RS) & Length (cm) & $\begin{array}{c}\text { Months of } \\
\text { Cultivation }\end{array}$ \\
\hline $30 \%$ & Little & 3.00 & $2.5-3.5$ & $3-4$ \\
$40 \%$ & Medium & 6.00 & $3.5-5.0$ & $4-5$ \\
$20 \%$ & Big & 15.00 & Above 6.0 & $5-6$ \\
$10 \%$ & Discard & - & - & - \\
\hline
\end{tabular}

The monthly depreciation value, were calculated based on the useful life of the materials, corresponding to the value that should be saved monthly until the object is destroyed. Thus, when some utensil or equipment reaches the end of its useful life, the enterprise will be able to cover the expenses for its replacement by acquiring a new one without worries or containment of resources.

Table 3- Investments required for the implementation of freshwater Angelfish (Pterophyllum scalare) in Brasília - DF, November 2014.

\begin{tabular}{|c|c|c|c|c|c|}
\hline Description & Amount & $\begin{array}{l}\text { Unit Value } \\
\text { (R\$) }\end{array}$ & Subtotal & $\%$ total & $\begin{array}{c}\text { Depreciation } \\
(\mathrm{R} \$)\end{array}$ \\
\hline \multicolumn{6}{|l|}{ Pre-Operational Cost } \\
\hline Land & 1 & $35,000.00$ & $3,5000.00$ & 51.38 & 0 \\
\hline Construction & 1 & - & 5127.00 & 7.53 & 21.36 \\
\hline $\begin{array}{l}\text { Hydraulic and electrical } \\
\text { installation }\end{array}$ & 1 & - & $4,888.09$ & 7.18 & 20.37 \\
\hline Fish & - & - & $11,758.00$ & 17.26 & 48.99 \\
\hline Filtration & - & - & $3,682.74$ & 5.41 & 117.37 \\
\hline Others & - & - & $2,934.16$ & 4.31 & 12.23 \\
\hline Adult individuals & 50 & 25.00 & $1,250.00$ & 1.83 & - \\
\hline \multicolumn{6}{|l|}{ Variable Monthly Costs } \\
\hline Live food & - & 65.00 & 65.00 & 0.10 & - \\
\hline Filtration & - & 228.20 & $1,590.10$ & 2.33 & - \\
\hline Feed for omnivorous fish & 910 & 0.29 & 266.63 & 0.39 & - \\
\hline $\begin{array}{l}\text { Water and medication } \\
\text { testing }\end{array}$ & 1 & 10.00 & 10.00 & 0.01 & - \\
\hline Packaging for sale & 1 & 8.90 & 15.00 & 0.02 & - \\
\hline Electricity & 449.25 & - & 94.34 & 0.14 & - \\
\hline Water from CAESB & 17.4 & 10.28 & 178.87 & 0.26 & - \\
\hline \multicolumn{6}{|l|}{ Fixed Monthly Costs } \\
\hline Monthly Pro-labore & 1 & $1,000.00$ & $1,000.00$ & 1.47 & - \\
\hline Monthly depreciation & 1 & 261.17 & 261.17 & 0.38 & - \\
\hline
\end{tabular}

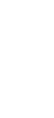

Table 4- Description of Total Investment for freshwater Angelfish (Pterophyllum scalare) in 12 months.

\begin{tabular}{lcc}
\hline Description of the Investment & Value (R\$) & $\%$ \\
\hline 1. Pre-Operational Investment & $64,639.99$ & 54 \\
2. Working Capital & $13,750.38$ & 11 \\
3. Fixed Monthly Cost & $15,134.04$ & 13 \\
4. Variable Monthly Cost & $26,639.28$ & 22 \\
\hline Total & $120,163.69$ & 10 \\
& & 0 \\
\hline
\end{tabular}

As indicators of economic viability (SALIM et al.,2005):

Break-even point: it is the representation of how much the company needs to sell in order to be able to pay all its costs in a certain period, without prejudice or profit.

Profitability: it is an economic indicator that is directly related to the competitiveness of the enterprise. Can be calculated as a percentage or in units sold.

Return on investment (ROI): quantifies the return on invested capital, being an indicator of business attractiveness.

Payback: consists of the time required for the investor to recover all the money used in the structuring of the enterprise, that is, the time necessary for the business to be paid.

Table 5- Planning of the enterprise in 10 years, for the cultivation of freshwater Angelfish (Pterophyllum scalare).

\begin{tabular}{lccc}
\hline $\begin{array}{l}\text { Annual Description Value } \\
\text { (R\$) }\end{array}$ & Year 1 & Year 2 - & Year 10 \\
\hline Pre-operational Investment & $64,639.99$ & 0 & 0 \\
Variable Monthly Costs & $2,219.94$ & $2,219.94$ & $2,219.94$ \\
Fixed Monthly Costs & $1,261.17$ & $1,261.17$ & $1,261.17$ \\
Total investment & $106,413.31$ & $106,413.31$ & $106,413.31$ \\
Total revenue & $6,300.00$ & $16,200.00$ & $16,200.00$ \\
Net Income (R\$) & $2,818.89$ & $12,718.89$ & $12,718.89$ \\
Point of Equilibrium (R\$) & 389.83 & 389.25 & 389.25 \\
Annual Balance Point & $4,678.00$ & $4,678.00$ & $4,678.00$ \\
(Units Sold) & (P 2,457, M & (P 2,457, M & (P 2,457, M \\
& 1,638, G 342) & 1,638, G 342) & 1,638, G 342) \\
Monthly Balance Point & 370 & 370 & 370 \\
(Units Sold) & (P 205, M 136, & (P 205, M 136, & (P 205, M 136, \\
& G 29) & G 29) & G 29) \\
Annual Contribution Margin & & & 0.86 \\
Index & 0.65 & 0.86 & 78.51 \\
Lucrability (\%) Annual & 44.74 & 78.51 & 11.95 \\
Rentability (\% per annum) & 2.65 & 11.95 & \\
\hline
\end{tabular}


The change in the marketing prices of fish can have a significant influence on profitability indicators. Therefore, an optimistic scenario was proposed, with the economy of inputs in the production, besides the sale of copies with higher market value. This can occur in the case of cultivating different color varieties or selling them to stores specializing in aquarium, where the prices and quality of animals are higher than those selling various animals. The pessimistic scenario consists in the survival of only $50 \%$ of the production, besides the reduction of the selling price of the animals.

Table 6- Financial analysis of an enterprise for the cultivation of freshwater Angelfish (Pterophyllum scalare) in three different scenarios.

\begin{tabular}{lcc}
\hline Description & Optimistic & Probably \\
\hline Pre-operating Cost (R\$) & $64,639.99$ & $64,639.99$ \\
Variable Monthly Cost (R\$) & $1,385.97$ & $2,219.94$ \\
Fixed Monthly Cost (R\$) & $1,261.17$ & $1,261.17$ \\
Total Revenue (R\$) & $9,500.00$ & $6,300.00$ \\
Working Capital (R\$) & $10,456.20$ & $13,750.38$ \\
Total annual investment (R\$) & $96,405.67$ & $106,413.3$ \\
& 19,602 & 0 \\
Point of Equilibrium (R\$) & 54 & 389.83 \\
Point of Equilibrium (No of Fish) & 6.43 & 108 \\
Contribution Margin Index & $6,852.86$ & 3.24 \\
Net Income (R\$) & 72.14 & 44.74 \\
Profitability (\%) & 7.11 & 2.65 \\
Profitability (\% per month) & 14 & 38 \\
Return on Investment (months) & &
\end{tabular}

In the first year of operation of the enterprise, the return on investment is already beginning, which reflects the good profitability indexes. However, it should be noted that initial investment and production costs are considered high for a small entrepreneur. And associated with this we have the requirement of a specialized manpower that knows how to deal with the maintenance of the recirculation system, besides the management care that will result in the good survival rates of the fish produced.

Comparing the results with a production venture of the popular clown fish, (Amphiprion ocellaris) the good results are similar, with a pay-back from 25 to 33 months, varying according to the sale price (Kodama et al., 2011). The high cost of implementing an enterprise for the intensive and indoor cultivation of ornamental species was also reported by Pomeroy and Balboa (2004), Kodama et al. (2011). Although the investment is considered high for a small entrepreneur, the cultivation of ornamental species requires a smaller investment than the investment for the cultivation of species of fish destined for human consumption, such as Rachycentron canadum, which had its economic feasibility evaluated for the offshore cultivation (Sanches et al., 2008) and Centropomus undecimalis (Sanches et al., 2014).

\section{CONCLUSION}

The intensive cultivation of freshwater Angelfish in a recirculation system is economically feasible and presents good profitability rates when compared to other fish production systems. However, due to the high investment it is not attractive to small entrepreneurs.

\section{REFERENCES}

Abraham, K. M. 2017. Growth performance of angelfish, Pterophyllum scalare fed with diferente live worm diets. Journal of Aquatic Biology \& Fisheries, 5, 116-122.

Almeida, P. M. 2016. História, memória e future da pesquisa de mercado no Brasil. Organicom, 13, (25), 117-128.

Azimirad, M.; Meshkini, S.; Ahmadifard, N.; Hoseinifar, S. H. 2016. The effects of feeding with synbiotic (Pediococcus acidilactici and fructooligosaccharide) enriched adult Artemia on skin mucus immune responses, stress resistance, intestinal microbiota and performance of angelfish (Pterophyllum scalare). Fish \& Shellfish, 54, (1), 516-522

Chapman, F.A.; Fitz-Coy, S.; Thunberg, J.T. 1997. Trade in Ornamental Fish. Journal of the World Aquaculture Society, 28, (1), 1-10.

Cacho, M. S. R. F.; Yamamoto, M. E.; Chellappa, S. 1999. Comportamento reprodutivo do Acarábandeira, Pterophyllum scalare Convier \& Valencinas (Osteichthyes, Cichlidae). Revista Brasileira de Zoologia. 16, (1), 653-664,

Faro, C. 1979. Elementos de engenharia econômica. $3^{\mathrm{a} e d .}$ São Paulo: Atlas. 328p.

Halachmi, I. 2006. System engineering for ornamental fish production in a recirculating aquaculture system. Aquaculture, 259, (1), 300-314. https://doi. org/10.1016/j.aquaculture.2006.05.046

Kodama, G.; Annunciação, W. F.; Sanches, E. G.; Gomes, C. H. A. M.; Tsuzuki, M. Y. 2011. Viabilidade econômica do cultivo do peixe palhaço, Amphiprion ocellaris, em sistema de recirculação. Boletim do Instituto de Pesca, 37, (1), 61-72.

Mathias, J.; Fernandes, J. B. K.; Giannecchini, L. G. Como criar Acará-bandeira. Globo Rural. 293 (Mar). [online] URL: $2010 \mathrm{http}: / /$ revistagloborural.globo. com/GloboRural/0,6993,EEC1708920-4530,00. html 
Ministério da Pesca e Aquicultura- MPA. Nova guia de transporte beneficia produtores e lojistas de peixes ornamentais. (Set) [online] URL: 2014 http://www. panoramadaaquicultura.com. $\mathrm{br} /$ novosite/?p $=4782$

Nayak, S. K. 2010 Probiotics and immunity: A fish perspective. Fish \& Shellfish Immunology, 29, (1), 2-14.

Piedrahita, R. H. 2003 Reducing the potential environmental impact of tank aquaculture effluents through intensification and recirculation. Aquaculture, 226, (1-4), 35-44.

Pomeroy, R. S. e Balboa, C. 2004. The financial feasibility of small-scale marine ornamental aquaculture in the Philippines. Asian Fisheries Science, 17, (1), 365-376.

Ribeiro, F.A.F.; Fernandes, J.B.K; Rodrigues, L.A. 2007. Desempenho de juvenis de Acará-bandeira (Pterophyllum scalare) com diferentes níveis de proteína bruta na dieta. Boletim Instituto de Pesca, 33, (2), 195-203.

Salim, C. S.; Hochman, N.; Ramal, A. C.; Ramal, S. A. 2005. Construindo planos de negócios. $3^{a}$ ed. Rio de Janeiro, Elsevier. 252p.

Sanches, E. G.; Seckendorff, R. W. V.; Henriques, M. B.; Fagundes, L.; Sebastiani, E. F. 2008. Viabilidade econômica do cultivo do bijupirá (Rachycentron canadum) em sistema offshore. Informações Econômicas, 38, (12), 42-51.

Sanches, E. G.; Silva, F. C.; Ramos, A. P. F. D. A. 2014. Viabilidade econômica do cultivo do Robaloflecha em empreendimentos de carcinicultura no nordeste do Brasil. Boletim do Instituto de Pesca, 40, (4), 577-588.

Silva, S. D.; Mendes, G. N.; Valença, A. R. 2008. Cultivo de pós-larvas de Macrobrachium rosenbergii (De Man, 1879) com os alevinos de Pterophyllum scalare (Heckel, 1840) e Carassius auratus (Günther, 1870) em laboratório. Boletim do Instituto de Pesca, 34, (3), 453-461.

Ribeiro, F. A. S.; Jorge, P. H.; Fernandes, J. B. K.; Sakomura, N. K. 2010 Densidade de estocagem para produção de Acará-bandeira em viveiros escavados em policultivo com Camarão-daamazônia. Revista Caatinga, 23, (4), 1-6.

Takahashi, L. S.; Silva, T. V.; Fernandes, J. B. K.; Biller, J. D.; Sandre, L. C. G. 2010. Efeito do tipo de alimento no desempenho produtivo de juvenis de Acará-bandeira (Pterophyllum scalare). Boletim do Instituto de Pesca, 36, (1), 1-8.

Veras, G. C.; Soares, L. M. O.; Brabo, M.F.; Paixão, D. J. M. R.; Dias, B. C. B.; Alves, A. X.; Murgas, L. D. S.; Campelo, D. A. V. 2016. Fotoperíodo e frequência alimentar na larvicultura do acarábandeira Pterophyllum scalare. Archivos de Zootecnia, 65, (252), 581-584.
Vidal Jr, M. V. 2007. Produção de Peixes Ornamentais. Viçosa - MG, Centro de Produções Técnicas. 202p.

Submetido: Julho/17

Revisado: Maio/18 Aceito:Julho/18

Publicado: Maio/19 